\title{
Effects of Sulphur Fertilizer on Copper Metabolism in Grazing Tibetan Sheep in Fertilized Pasture
}

\author{
Bowen Zhai ${ }^{1}$, Kui Zhao', Xiaoyun Shen ${ }^{2,3,4 *}$ \\ ${ }^{1}$ School of Materials and Architectural Engineering, Guizhou Normal University, Guiyang 550025, China \\ ${ }^{2}$ State Key Laboratory of Sheep Genetic Improvement and Healthy Production, Xinjiang Academy \\ of Agricultural and Reclamation Sciences, Shihezi 832000, Xinjiang, China \\ ${ }^{3}$ School of Life Science and Engineering, Southwest University of Science and Technology, \\ Mianyang 621010, China \\ ${ }^{4}$ World Bank Poverty Alleviation Project Office in Guizhou, Southwest China, Guiyang 550004, China
}

Received: 20 February 2021

Accepted: 21 April 2021

\begin{abstract}
To explore the impact of sulfur $(\mathrm{S})$ fertilization on copper $(\mathrm{Cu})$ metabolism in grazing Tibetan sheep, fertilizing and grazing experiments were conducted in the Southwest Grand Grassland, China. The tested pasture was randomly divided into four parts by the fencing device $\left(2 \mathrm{hm}^{2} /\right.$ part). The pasture received ammonium sulfate $\left[\left(\mathrm{NH}_{4}\right)_{2} \mathrm{SO}_{4}\right]$ treatment in summer in $2020\left(0,300,400\right.$, and $500 \mathrm{~kg} / \mathrm{hm}^{2}$ for part I, part II, part III, and part IV, respectively). 24 Tibetan sheep (one year old) were randomly divided into four groups, and assigned to the selected pastures (part I, part II, part III, and part IV for group I, group II, group III, and group IV, respectively). The grazing experiments lasted for 90 days. The results showed that the contents of nitrogen $(\mathrm{N})$ and $\mathrm{S}$ in fertilized forage were markedly higher than those in unfertilized grass $(P<0.01)$, but there was no significant difference among fertilized forages. The contents of $\mathrm{Cu}$ in blood and liver in the Tibetan sheep from fertilized pasture were extremely lower than those in animals from unfertilized pasture $(P<0.01)$. The contents of $\mathrm{Hb}$ and PCV in the tested sheep from fertilized pasture were extremely higher than those in sheep from unfertilized pasture. The activities of serum SOD, GSH-Px, T-AOC, Cp, and CAT in sheep from fertilized pasture were extremely lower than those in sheep from no fertilized pasture $(P<0.01)$, but there were no obvious differences among the Tibetan sheep from fertilized pasture $(P>0.05)$. The contents of MDA in the Tibetan sheep from fertilized pasture were significantly higher than those in animals from no fertilized pasture $(P<0.01)$. There was no obvious difference among the Tibetan sheep from fertilized pasture $(\mathrm{P}>0.05)$. Therefore, $\left(\mathrm{NH}_{4}\right)_{2} \mathrm{SO}_{4}$ fertilization not only greatly influenced the contents of $\mathrm{S}$ and $\mathrm{N}$
\end{abstract}

*e-mail: xyshen@swust.edu.cn 
in forage, but also extremely decreased $\mathrm{Cu}$ contents of animal tissues in the Tibetan sheep from fertilized ranges.

Keywords: the Southwest Grand Grassland, pastureland management, tibetan sheep, copper metabolism, sulphur fertilizer

\section{Introduction}

The Qinghai-Tibet Plateau is an alpine meadow ecosystem of the highest altitude in the world, and is also the largest pasture land in Southwest China [1]. The Southwest Grand Grassland is located in the Southeast of the Qinghai-Tibet Plateau, and is also the highest primary productivity in Asia. Tibetan sheep, Hequ horse, and Choko yak are born and bred there $[2,3]$.

Tibetan sheep are vital to the production system of the Southwest Grand Grassland, China. Over the last 10 years, the local government was trying to improve the nomadic lifestyle of local herdsmen. More and more natural pastures were fenced in the Southwest Grand Grassland. The feeding areas of the Tibetan sheep had been rigorously restricted in fenced pasture, and nomadic behavior had been seriously interrupted. As a result, sulfur (S) deprivation had sharply risen in forage in the Southwest Grand Grassland [4, 5]. $\mathrm{S}$ as a nutrient is very important in plants and animals $[6,7]$. In recent years, to improve productivity, the local herdsmen are trying to increase $\mathrm{S}$ content in forage. Ammonium sulfate $\left[\left(\mathrm{NH}_{4}\right)_{2} \mathrm{SO}_{4}\right]$ fertilization was conducted during the summer grazing season in the Southwest Grand Grassland. Molybdenum (Mo) content in forage is a commonly recognized contributor to copper $(\mathrm{Cu})$ deprivation in animals, but adequate dietary $\mathrm{S}$ nutrient is required. Mo combines with $\mathrm{S}$ element to form thiomolybdate complex, and binds with $\mathrm{Cu}$ element to form insoluble complex, rendering $\mathrm{Cu}$ nutrient unavailable for absorption [8]. Therefore, the effect of increasing $\mathrm{S}$ concentration in forage on mineral status of grazing Tibetan sheep is an important issue. Shen has reported that the effect of $\left(\mathrm{NH}_{4}\right)_{2} \mathrm{SO}_{4}$ treatment on $\mathrm{S}$ contents of plants in natural pasture in the Shouqu Prairie in Southwest China. In this study, $\left(\mathrm{NH}_{4}\right)_{2} \mathrm{SO}_{4}$ fertilization resulted in high $\mathrm{S}$ contents in plant $(0.71 \%)$ compared to fertilized plant with ammonium nitrate $\left(\mathrm{NH}_{4} \mathrm{NO}_{3}\right)(0.18 \%)$ [9]. Nevertheless, the effects of different levels of $\left(\mathrm{NH}_{4}\right)_{2} \mathrm{SO}_{4}$ fertilization on $\mathrm{Cu}$ metabolism have not been reported in grazing Tibetan sheep.

The objective of this research was to determine the influences of different levels of $\left(\mathrm{NH}_{4}\right)_{2} \mathrm{SO}_{4}$ fertilization on $\mathrm{Cu}$ metabolism of grazing Tibetan sheep in the Southwest Grand Grassland.

\section{Materials and Methods}

\section{Experiment Design}

$\left(\mathrm{NH}_{4}\right)_{2} \mathrm{SO}_{4}$ was purchased from Xinan Chemical Industry Group Co., Ltd, with purity of no less than 99\%. The tested pasture is located in the Southwest Grand Grassland in Sichuan Province, China. The mineral elements in soil were determined at the start and end of the research. The tested pasture was randomly divided into four parts by the fencing device $\left(2 \mathrm{hm}^{2} /\right.$ part). The pasture received $\left(\mathrm{NH}_{4}\right)_{2} \mathrm{SO}_{4}$ treatment in summer in $2020\left(0,300,400\right.$, and $500 \mathrm{~kg} / \mathrm{hm}^{2}$ for part I, part II, part III, and part IV, respectively). A total of 24 Tibetan sheep were randomly divided into four groups, and assigned to the selected pastures (part I, part II, part III, and part IV for group I, group II, group III, and group IV, respectively). The grazing experiment lasted for 90 days.

\section{Sample Collection}

The samples of soil and plant were collected at the start and end of the experiment. The samples of whole blood were collected from the jugular vein at the end of the experiment. The samples of serum were collected in vacuum tubes of $1 \%$ heparin sodium, centrifuged at $3000 \times \mathrm{g}$ for $15 \mathrm{~min}$, then stored at $4^{\circ} \mathrm{C}$. The samples of liver were collected by a trained technician using techniques previously described.

\section{Sample Analysis}

The samples of soil and forage were analyzed for mineral contents as described for Yuan (2012) [8]. The samples of blood and liver were handled and analyzed for mineral contents of $\mathrm{Cu}$, zinc $(\mathrm{Zn})$, manganese $(\mathrm{Mn})$, iron (Fe), and Mo as described for Huo et al. (2019) [10]. The contents of nitrogen $(\mathrm{N})$ and $\mathrm{S}$ in soil and forage were analyzed as described for Shen (2009) [9].

The blood physiological parameters including hemoglobin $(\mathrm{Hb})$, erythrocyte count $(\mathrm{RBC})$, packed cell volume (PCV), and white blood cell count (WBC) were analyzed as described for Yuan et al. (2013) [11]. The blood biochemical parameters including total antioxidant capacity (T-AOC), superoxide dismutase (SOD), glutathione peroxide (GSH-Px), catalase (CAT), malondialdehyde (MDA), and ceruloplasmin (Cp) were analyzed as described for Shen (2011) [12]. 


\section{Data Analyses}

The tested data was analyzed by the statistical package (SPSS, version 21.0, Inc., Chicago, Illinois, USA), and presented in the form of mean \pm standard deviation.

\section{Results}

\section{Influences of S Fertilization on Mineral Content in Forage $\mathrm{S}$}

As in Table 1, compared to unfertilized pasture (control group), the values of $\mathrm{S}$ and $\mathrm{N}$ in forage were considerably higher in fertilized pasture $(P<0.01)$, and the values of $\mathrm{Cu}$ in forage were considerably lower in fertilized pasture $(P<0.01)$, nevertheless there was no considerable difference among part II, part III, and part IV $(P>0.05)$.

\section{Influences of S Fertilization on Mineral Content in Animal Tissues}

As in Table 2 and Table 3, the $\mathrm{Cu}$ values in blood and liver in group I (control group) were considerably higher than those in group II, group III, and group IV $(P<0.01)$, nevertheless there was no considerable difference among group II, group III, and group IV $(P>0.05)$. The $\mathrm{S}$ values in blood and liver in group I (control group) were considerably lower than those in group II, group III, and group IV $(P<0.01)$, nevertheless there was no considerable difference among group II, group III, and group IV $(P>0.05)$. The Fe values in blood in group I (control group) were extremely higher than those in group II, group III, and group IV $(P<0.01)$. There were no considerable difference among Fe contents in liver in group I, group II, group III, and group IV $(P>0.05)$.

\section{Influences of S Fertilization on Physiological Parameters in Grazing Animals}

As in Table 4, compared to group I (control group), the values of $\mathrm{Hb}$ and $\mathrm{PCV}$ were considerably decreased in group II, group III, and group IV $(P<0.01)$, nevertheless there was no considerable difference among group II, group III, and group IV $(P>0.05)$. Anemia has occurred in group II, group III, and $\mathrm{g}$ roup IV.

\section{Influences of S Fertilization on Antioxidant Parameters in Grazing Animals}

As in Table 5, compared to group I (control group), the levels of T-AOC, SOD, GSH-Px, CAT,

Table 1. Effects of fertilized pasture with $\left(\mathrm{NH}_{4}\right)_{2} \mathrm{SO}_{4}$ on mineral contents in forage.

\begin{tabular}{|c|c|c|c|c|}
\hline Items & Part I (control) & Part II & Part III & Part IV \\
\hline $\mathrm{N}(\mathrm{mg} / \mathrm{kg})$ & $2.23 \pm 0.21^{\mathrm{b}}$ & $3.92 \pm 0.25^{\mathrm{a}}$ & $4.13 \pm 0.22^{\mathrm{a}}$ & $4.25 \pm 0.23^{\mathrm{a}}$ \\
\hline $\mathrm{Mn}(\mathrm{mg} / \mathrm{kg})$ & $65.53 \pm 6.26$ & $66.72 \pm 6.91$ & $65.37 \pm 6.67$ & $66.87 \pm 6.69$ \\
\hline $\mathrm{Zn}(\mathrm{mg} / \mathrm{kg})$ & $84.64 \pm 12.26$ & $84.67 \pm 8.17$ & $87.61 \pm 9.93$ & $85.89 \pm 6.29$ \\
\hline $\mathrm{Cu}(\mathrm{mg} / \mathrm{kg})$ & $7.26 \pm 0.63^{\mathrm{a}}$ & $3.92 \pm 0.41^{\mathrm{b}}$ & $3.72 \pm 0.35^{\mathrm{b}}$ & $3.64 \pm 0.61^{\mathrm{b}}$ \\
\hline $\mathrm{Fe}(\mathrm{mg} / \mathrm{kg})$ & $318.64 \pm 22.59$ & $325.43 \pm 21.37$ & $319.24 \pm 23.17$ & $321.52 \pm 22.37$ \\
\hline $\mathrm{Mo}(\mathrm{mg} / \mathrm{kg})$ & $1.27 \pm 0.11$ & $1.25 \pm 0.13$ & $1.28 \pm 0.17$ & $1.23 \pm 0.13$ \\
\hline $\mathrm{S}(\%)$ & $0.21 \pm 0.02^{\mathrm{b}}$ & $0.39 \pm 0.05^{\mathrm{a}}$ & $0.41 \pm 0.07^{\mathrm{a}}$ & $0.42 \pm 0.03^{\mathrm{a}}$ \\
\hline
\end{tabular}

Different letters in the same line indicate significant difference at $P<0.01$ level

Table 2 Effects of fertilized pasture with $\left(\mathrm{NH}_{4}\right)_{2} \mathrm{SO}_{4}$ on mineral contents in blood

\begin{tabular}{|c|c|c|c|c|}
\hline Items & Group I (control) & Group II & Group III & Group IV \\
\hline $\mathrm{Mn}(\mathrm{mg} / \mathrm{kg})$ & $0.72 \pm 0.07$ & $0.71 \pm 0.13$ & $0.73 \pm 0.12$ & $0.71 \pm 0.11$ \\
\hline $\mathrm{Zn}(\mathrm{mg} / \mathrm{kg})$ & $8.47 \pm 0.19$ & $8.55 \pm 0.17$ & $8.58 \pm 0.18$ & $8.44 \pm 0.21$ \\
\hline $\mathrm{Cu}(\mathrm{mg} / \mathrm{kg})$ & $0.66 \pm 0.05^{\mathrm{a}}$ & $0.38 \pm 0.03^{\mathrm{b}}$ & $0.32 \pm 0.02^{\mathrm{b}}$ & $0.31 \pm 0.03^{\mathrm{b}}$ \\
\hline $\mathrm{Fe}(\mathrm{mg} / \mathrm{kg})$ & $374.91 \pm 38.22^{\mathrm{a}}$ & $321.84 \pm 40.21^{\mathrm{b}}$ & $319.83 \pm 55.20^{\mathrm{b}}$ & $312.74 \pm 38.21^{\mathrm{b}}$ \\
\hline $\mathrm{Mo}(\mathrm{mg} / \mathrm{kg})$ & $0.07 \pm 0.02$ & $0.08 \pm 0.02$ & $0.09 \pm 0.01$ & $0.07 \pm 0.02$ \\
\hline $\mathrm{S}(\mathrm{mmol} / \mathrm{L})$ & $38.78 \pm 3.32^{\mathrm{b}}$ & $52.12 \pm 5.73^{\mathrm{a}}$ & $54.73 \pm 5.33^{\mathrm{a}}$ & $55.13 \pm 4.76^{\mathrm{a}}$ \\
\hline
\end{tabular}

Different letters in the same line indicate significant difference at $P<0.01$ level 
Table 3. Effects of fertilizing pasture with $\left(\mathrm{NH}_{4}\right)_{2} \mathrm{SO}_{4}$ on mineral contents in liver.

\begin{tabular}{|c|c|c|c|c|}
\hline Items & Group I (control) & Group II & Group III & Group IV \\
\hline $\mathrm{Mn}(\mathrm{mg} / \mathrm{kg})$ & $5.77 \pm 0.36$ & $5.75 \pm 0.29$ & $5.69 \pm 0.35$ & $5.83 \pm 0.33$ \\
\hline $\mathrm{Zn}(\mathrm{mg} / \mathrm{kg})$ & $76.35 \pm 5.82$ & $73.68 \pm 5.21$ & $74.43 \pm 5.57$ & $72.83 \pm 4.79$ \\
\hline $\mathrm{Cu}(\mathrm{mg} / \mathrm{kg})$ & $73.26 \pm 6.17^{\mathrm{a}}$ & $58.42 \pm 3.55^{\mathrm{b}}$ & $53.21 \pm 3.37^{\mathrm{b}}$ & $59.22 \pm 3.37^{\mathrm{b}}$ \\
\hline $\mathrm{Fe}(\mathrm{mg} / \mathrm{kg})$ & $351.08 \pm 37.12$ & $355.12 \pm 18.54$ & $358.07 \pm 13.35$ & $354.34 \pm 19.16$ \\
\hline $\mathrm{Mo}(\mathrm{mg} / \mathrm{kg})$ & $2.98 \pm 0.30$ & $2.82 \pm 0.23$ & $2.79 \pm 0.22$ & $2.81 \pm 0.23$ \\
\hline $\mathrm{S}(\%)$ & $0.21 \pm 0.02^{\mathrm{b}}$ & $0.35 \pm 0.05^{\mathrm{a}}$ & $0.36 \pm 0.07^{\mathrm{a}}$ & $0.37 \pm 0.03^{\mathrm{a}}$ \\
\hline
\end{tabular}

Different letters in the same line indicate significant difference at $P<0.01$ level

Table 4. Effects of fertilizing pasture with $\left(\mathrm{NH}_{4}\right)_{2} \mathrm{SO}_{4}$ on physiological indexes in blood.

\begin{tabular}{|c|c|c|c|c|}
\hline Items & Group I (control) & Group II & Group III & Group IV \\
\hline $\mathrm{Hb}\left(\mathrm{g} / \mathrm{L}^{-1}\right)$ & $103.27 \pm 8.57^{\mathrm{a}}$ & $85.77 \pm 6.67^{\mathrm{b}}$ & $82.98 \pm 11.93^{\mathrm{b}}$ & $81.37 \pm 6.37^{\mathrm{b}}$ \\
\hline $\mathrm{RBC}\left(10^{12} / \mathrm{L}\right)$ & $7.83 \pm 0.57$ & $7.53 \pm 0.61$ & $7.83 \pm 0.52$ & $7.72 \pm 0.65$ \\
\hline $\mathrm{PCV}(\%)$ & $35.52 \pm 2.30^{\mathrm{a}}$ & $25.42 \pm 2.13^{\mathrm{b}}$ & $23.51 \pm 1.73^{\mathrm{b}}$ & $21.03 \pm 2.50^{\mathrm{b}}$ \\
\hline WBC $\left(10^{9} / \mathrm{L}\right)$ & $10.52 \pm 0.57$ & $9.87 \pm 0.67$ & $9.94 \pm 0.77$ & $10.43 \pm 0.98$ \\
\hline
\end{tabular}

Different lowercase letters in the same trade indicate significant difference at $P<0.01$ level

Table 5. Effects of fertilizing pasture with $\left(\mathrm{NH}_{4}\right)_{2} \mathrm{SO}_{4}$ on antioxidant capacity in blood.

\begin{tabular}{|c|c|c|c|c|}
\hline Items & Group I (control) & Group II & Group III & Group IV \\
\hline SOD $(\mathrm{IU} / \mathrm{mL})$ & $73.56 \pm 2.92^{\mathrm{a}}$ & $67.51 \pm 4.62^{\mathrm{b}}$ & $66.53 \pm 3.82^{\mathrm{b}}$ & $68.71 \pm 4.33^{\mathrm{b}}$ \\
\hline GSH-Px $(\mathrm{IU} / \mathrm{mL})$ & $45.32 \pm 3.22^{\mathrm{a}}$ & $43.56 \pm 2.72^{\mathrm{b}}$ & $44.34 \pm 4.13^{\mathrm{b}}$ & $44.23 \pm 3.92^{\mathrm{b}}$ \\
\hline T-AOC $(\mathrm{IU} / \mathrm{mL})$ & $8.21 \pm 0.66^{\mathrm{a}}$ & $6.65 \pm 0.85^{\mathrm{b}}$ & $6.59 \pm 0.96^{\mathrm{b}}$ & $6.68 \pm 0.63^{\mathrm{b}}$ \\
\hline CAT $(\mathrm{IU} / \mathrm{mL})$ & $3.83 \pm 0.15^{\mathrm{a}}$ & $2.23 \pm 0.12^{\mathrm{b}}$ & $2.17 \pm 0.11^{\mathrm{b}}$ & $2.12 \pm 0.12^{\mathrm{b}}$ \\
\hline MDA $(\mathrm{nmol} / \mathrm{mL})$ & $25.25 \pm 2.1^{\mathrm{7}} \mathrm{b}$ & $37.23 \pm 2.87^{\mathrm{a}}$ & $38.73 \pm 3.19^{\mathrm{a}}$ & $39.31 \pm 2.23^{\mathrm{a}}$ \\
\hline Cp $(\mathrm{BU} / \mathrm{dL})$ & $8.73 \pm 0.87^{\mathrm{a}}$ & $5.46 \pm 1.02^{\mathrm{b}}$ & $5.33 \pm 0.67^{\mathrm{b}}$ & $5.55 \pm 0.62^{\mathrm{b}}$ \\
\hline
\end{tabular}

Different letters in the same line indicate significant difference at $P<0.01$ level

and $\mathrm{Cp}$ in serum were considerably decreased in group II, group III, and group IV $(P<0.01)$, and the levels of MDA were considerably increased in group II, group III, and group IV $(P<0.01)$, nevertheless there was no considerable difference among group II, group III, and group IV $(P>0.05)$.

\section{Discussion}

\section{Influences of S Fertilization on Mineral Contents in Forages}

$\mathrm{N}$ and $\mathrm{S}$ are important nutrients in plants. More and more studies have shown that fertilized forages with $\left(\mathrm{NH}_{4}\right)_{2} \mathrm{SO}_{4}$ can considerably increase the contents of $\mathrm{N}$ and $\mathrm{S}$ in plants. Shen has also reported a 3-year study on investigating the effect of $\left(\mathrm{NH}_{4}\right)_{2} \mathrm{SO}_{4}$ treatment on $\mathrm{S}$ contents of plants in the Shouqu Prairie in Southwest China) [9]. Their results showed that the contents of $\mathrm{N}$ and $\mathrm{S}$ in forage were considerably increased in fertilized pasture. Nevertheless, to date, no researcher has investigated the influences of different levels of $\left(\mathrm{NH}_{4}\right)_{2} \mathrm{SO}_{4}$ fertilization on $\mathrm{Cu}$ metabolism in grazing animals.

\section{Influences of S Fertilization on Mineral Contents in Animal Tissues}

The antagonistic effect of $\mathrm{S}$ nutrient on $\mathrm{Cu}$ metabolism in animals has been very well recognized. $\mathrm{S}$ element combines with Mo element to form a thiomolybdate complex in rumen. Thiomolybdates bind with $\mathrm{Cu}$ element to form an insoluble complex, rendering $\mathrm{Cu}$ nutrient unavailable for absorption. Therefore, the $\mathrm{Cu}$ values in blood and liver in group I (control 
group) were considerably higher than those in group II, group III, and group IV. Decrease in circulating $\mathrm{Cu}$ level in blood is associated with $\mathrm{Cu}$ content in liver of approximately $40 \mathrm{mg} / \mathrm{kg}$ and lower [13, 14]. Once these contents are achieved, sheep are considered $\mathrm{Cu}$ deprivation. $\mathrm{Cu}$ content in liver below $75 \mathrm{mg} / \mathrm{kg}$ is considered deprivation for the Tibetan sheep $[15,16]$. Therefore, the Tibetan sheep in current studies had been considered $\mathrm{Cu}$ deprivation when they initially entered the experiment, because initial $\mathrm{Cu}$ contents in liver in the tested sheep were $73.26 \pm 6.17 \mathrm{mg} / \mathrm{kg}$.

\section{Influences of S Fertilization on Physiological Parameters in Grazing Animals}

Most of $\mathrm{Cu}$ element in blood is showed as ceruloplasmin $(\mathrm{Cp})$, which plays a key role in greatly increasing the rate of $\mathrm{Fe}$ saturation of transferrin, so in the absorption and transport of $\mathrm{Fe}$, and in the utilization of $\mathrm{Fe}$ by the bone marrow in animals [17, 18]. The lack of $\mathrm{Cu}$ nutrient often leads to extreme decrease of $\mathrm{Cp}$ content in blood [19-21]. Therefore, the low content of $\mathrm{Cu}$ in forage not only considerably reduces the level of $\mathrm{Cp}$ but also causes sheep anemia. In our studies, the values of $\mathrm{Hb}$ and $\mathrm{PCV}$ were considerably lower than those in group II, group III, and group IV.

\section{Influences of S Fertilization on Antioxidant Parameters in Grazing Animals}

SOD per mole contains 2 eq (chemical equivalent) of $\mathrm{Cu}$. $\mathrm{Cu}$ element may be reversibly removed, and it is required for activity $[22,23]$. Cu deficiency often leads to low $\mathrm{Cp}$ content in blood, and decreases absorption of Fe [24, 25]. Therefore, the levels of T-AOC, CAT, and SOD in the Tibetan sheep from fertilized pastures were extremely decreased, and the contents of MDA were considerably increased. Antioxidant system is the defense system of organisms for scavenging free radicals, including mainly vitamins, cysteine, glutathione, $\mathrm{Cu}, \mathrm{Mn}, \mathrm{Zn}, \mathrm{Fe}, \mathrm{SOD}, \mathrm{GSH}-\mathrm{Px}, \mathrm{CAT}$, etc $[26,27]$. SOD, as a key metal enzyme, is very widely existing in aerobic organisms. It plays a very important role in the oxidation resistance of organisms, and can very rapidly catalyze the superoxide anion $\left(\mathrm{O}^{2-}\right)$ to produce disproportionation reaction, and protect organism cells from damage from free radicals in metabolism [28-30]. CAT can decompose $\mathrm{H}_{2} \mathrm{O}_{2}$ into molecular oxygen and water very rapidly and clear $\mathrm{H}_{2} \mathrm{O}_{2}$ in organism, so as to protect organism cells from $\mathrm{H}_{2} \mathrm{O}_{2}$ [31-33]. T-AOC is an important parameter for evaluating antioxidant capacity in organisms. It can very rapidly reflect the compensatory capacity to external stimuli and the metabolism capacity of free radicals in organisms [34-36]. The significant decrease of T-AOC level will considerably increase the abundance of lipid peroxides and free radicals of organisms. MDA is a lipid peroxide of organism, which can reflect very rapidly the degree of lipid peroxidation in organisms [37-39].

\section{Conclusion}

Based on the results, the fertilized pasture not only increased the contents of $\mathrm{S}$ and $\mathrm{N}$ in forage, but also severely disrupted the blood parameters and considerably decreased $\mathrm{Cu}$ contents in blood and liver.

\section{Acknowledgements}

This work was supported by the Innovation and Development Supporting Plan Project of Key Industries in Southern Xinjiang (2021DB014) and the National Natural Science Foundation of China (41671041).

\section{Compliance with Ethical Standards}

Tested Tibetan sheep were cared for as outlined in the Guide for the Care and Use of Tested Animals in Research and Teaching Consortium. Sample collections from the Tibetan sheep were approved by Southwest University of Science and Technology, Institutional Animal Care and Use Committee (Project B-0197). The studies were approved by the relevant ranchers, with the written consent of all participants.

\section{Conflict of Interest}

The authors declare that they have no conflict of interest.

\section{References}

1. ZHAO K., CHI Y.K., SHEN X.Y. Studies on edema pathema in Hequ horse in the Qinghai-Tibet Plateau. Biological Trace Element Research, 198, 142-148, 2020.

2. ZHAO K., HUO B., SHEN X.Y. Studies on Antioxidant Capacity in Selenium- deprived the Choko Yak in the Shouqu Prairie. Biological Trace Element Research, 2020. https:// doi.org/10.1007/s12011- 020-02461-9

3. SHEN X.Y., DU G.Z., LI H. Studies of a naturally occurring molybdenumin- duced copper deficiency in the yak. The Veterinary Journal, 171 (2), 352, 2006.

4. SONG C.J., SHEN X.Y. Effects of Environmental zinc deficiency on antioxidant system function in Wumeng semi-fine wool sheep. Biological Trace Element Research, 195 (1), 110, 2020.

5. HUO B., WU T., SONG C.J., SHEN X.Y. Effects of selenium deficiency in the environment on antioxidant systems of Wumeng semi-fine wool sheep. Polish Journal of Environmental Studies, 29 (2), 1649, 2020.

6. CHI Y.K., XIONG K.N., CHEN H., MIN X.Y., XIAO H., LIAO J.J., SHEN X.Y. Effect of grazing to copper pollution meadow on copper metabolism in Wumeng semi-fine wool sheep. Polish Journal of Environmental Studies, 28 (3), 1083, 2019.

7. SHEN X.Y., CHI Y.K., XIONG K.N. The effect of heavy metal contamination on humans and animals in the 
vicinity of a zinc smelting facility. PLOS ONE, 14 (10), e0207423, 2019.

8. YUAN R. Effect of fertilizer treatment to copper pollution meadow on copper metabolism in Guizhou semi-fine wool sheep. Lanzhou University: Lanzhou, China, 10, 2012 [In Chinese].

9. SHEN X.Y. Effect of nitrogenous fertilizer treatment on mineral metabolism in grazing yaks. Agricultural Sciences in China, 8 (003), 361, 2009.

10. HUO B., WU T., CHI Y.K., MING X.Y., SHEN X.Y. Effects of molybdenum fertilizer application on copper metabolism of Wumeng semi-fine wool sheep in copper polluted grassland. Journal of Domestic Animal Ecology, 40 (7), 44, 2019 [In Chinese].

11. YUAN R., LI L.J., WU Q.W., DU G.Z. Copper deficiency in Guizhou semi-fine wool sheep on pasture in southwest China karst mountain area. African Journal of Biotechnology, 10 (74), 17043, 2013.

12. SHEN X.Y. Studies of wool-eating ailment in Guizhou semi-fine wool sheep. Agricultural Sciences in China, 10 (10), 1618, 2011

13. KENFO H., MEKASHA Y.,TADESSE Y. A study on sheep farming practices in relation to future production strategies in Bensa district of Southern Ethiopia. Tropical Animal Health and Production, 50 (4), 865, 2018.

14. NEGEWO T., MELAKU S., ASMARE B., TOLERA A. Performance of Arsi-Bale sheep fed urea treated maize cob as basal diet and supplemented with graded levels of concentrate mixture. Tropical Animal Health and Production, 50 (3), 1209, 2018.

15. SHEN X.Y., HUO B., GAN S.Q. Effects of nano-selenium on antioxidant capacity in se-deprived tibetan gazelle (procapra picticaudata) in the Qinghai-Tibet plateau. Biological Trace Element Research, 199, 981, 2021.

16. ARAUJO A.R., RODRIGUEZ N.M., ROGERIO M.C.P., BORGES I., SALIBA E.O.S., SANTOS S.A., POMPEU R.C.F.F., FERNANDES F.E.P., MONTEIRO J.P., MUIR J.P. Nutritional evaluation and productivity of supplemented sheep grazing in semiarid rangeland of northeastern Brazil. Tropical Animal Health and Production, 51 (3), 957, 2018.

17. SHEN X.Y., HUO B., WU T., SONG C.J., CHI Y.K. iTRAQ-based proteomic analysis to identify molecular mechanisms of the selenium deficiency response in the Przewalski's gazelle. Journal of Proteomics, 203, 103389, 2019.

18. KHAN Z.I., AHMAD K., ASHRAF I., KHAN A., CAZZATO E. Appraisal of trace metal elements in soil,forage and animal continuum: a case study on pasture irrigated with sewage water. Philippine Agricultural Scientist, 99 (1), 80, 2016.

19. SHEN X.Y., JIANG H.M., YUAN R., JIA Z.H. Effects of grassland fertilization on forage and grazing of Guizhou semi-fine wool sheep. Acta Pratacul Turae Sin, 21 (3), 275, 2012 [In Chinese]

20. KANDIWA E., NGUARAMBUKA U., CHITATE F., SAMKANGE A., MUSHONGA B. Production performance of sheep and goat breeds at a farm in a semi-arid region of Namibia. Tropical Animal Health and Production, 52 (1): 695-699, 2020.

21. SHEN X.Y., DU G.Z., LI H. Studies of a naturally occurring molybdenum- induced copper deficiency in the yak. The Veterinary Journal, 71 (2), 352, 2006.

22. SHEN X.Y., DU G.Z., CHEN Y.M., FAN B.L. Copper deficiency in yaks on pasture in western China. Canadian Veterinary Journal-revue Veterinaire Canadienne, 47 (9),
902, 2006.

23. SHEN X.Y., JIANG Z.G. Changes of trace elements in forage grass of the first meander of the Yellow River. Chinese Journal of Grassland, 30 (4), 118, 2008.

24. SHEN X.Y., MIN X.Y., ZHANG S.H., SONG C.J., XIONG K.N. Effect of heavy metal contamination in environment on antioxidant function in Wumeng semi-fine wool sheep in the southwest China. Biological Trace Element Research, 198 (2), 505, 2020.

25. SHEN X.Y., SONG C.J. Responses of Chinese merino sheep (junken type) on copper-deprived natural pasture. Biological Trace Element Research, 199, 989, 2021.

26. SHEN X.Y., JIANG Z.G. Serum biochemical values and mineral contents of tissues in Przewalski's and Tibetan gazelles. African Journal of Biotechnology, 11 (3), 718, 2012.

27. SONG C.J., GAN S.Q., SHEN X.Y. Effects of nano-copper poisoning on immune and antioxidant function in the Wumeng semi-fine wool sheep. Biological Trace Element Research, 198, 515, 2020.

28. SONG C.J., GAN S.Q., HE J., SHEN X.Y. Effects of nanozinc on immune function in Qianbei-pockmarked goats. Biological Trace Element Research, 199 (2), 578, 2021.

29. WU T., SONG M.L., SHEN X.Y. Seasonal dynamics of copper deficiency in Wumeng semi-fine wool sheep. Biological Trace Element Research, 197, 487, 2020.

30. SHEN X.Y., SONG C.J., WU T. Effects of nano-copper on antioxidant function in copper-deprived Guizhou black goats. Biological Biological Trace Element Research, 2020. https://doi.org/10.1007/s12011-020-02342-1

31. LI Y.F., HE J., SHEN X.Y. Effects of nano-selenium poisoning on immune function in the Wumeng semi-fine wool sheep. Biological Trace Element Research, 2020. https://doi.org/10.1007/s12011-020-02408-0

32. HUO B., WU T., SONG C.J., SHEN X.Y. Studies of selenium deficiency in the Wumeng semi-fine wool sheep. Biological Trace Element Research, 194 (1), 152, 2019.

33. WANG Y.C., JIANG L., LI Y.F., LUO X.Y., HE J. Effect of different selenium supplementation levels on oxidative stress, cytokines, and immunotoxicity in chicken thymus. Biological Trace Element Research, 172 (2), 488, 2016.

34. HA H.Y., ALFULAIJ N., BERRY M.J., SEALE L.A. From selenium absorption to selenoprotein degradation. Biological Trace Element Research, 192 (1), 26, 2019.

35. HUMA N., SAJID A., KHALID A., WARDAH H., MOAZAMA B., SHAKEELA P., SADIA M., SAJIDA M. Toxic effect of insecticides mixtures on antioxidant enzymes in different organs of fish, Labeo rohita. Pakistan Journal of Zoology, 51, 1355, 2019

36. BANO I., MALHI M., LAKHO S.A., LEGHARI A. Effect of dietary selenium yeast supplementation on morphology and antioxidant status in tests of Zoology, 51 (3), 979, 2019.

37. CHI Y.K, ZHANG Z.Z., SONG C.J, XIONG K.N, SHEN X.Y. Effects of fertilization on physiological and biochemical parameters of Wumeng Sheep in China's Wumeng Prairie. Polish Journal of Environmental Studies, 29 (1), 79, 2019.

38. CHEN M., MAHFUZ S., CUI Y., JIA L.Y., LIU Z.J., SONG $\mathrm{H}$. The antioxidant status of serum and egg yolk in layer fed with mushroom stembase (flammulina velutipes). Pakistan Journal of Zoology, 52 (1), 389, 2019.

39. KANAFCHIAN M., ESMAEILZADEH S., MAHJOUB S., RAHSEPAR M., GHASEMI M. Status of serum copper, magnesium, and total antioxidant capacity in patients with polycystic ovary syndrome. Biological Trace Element Research, 193, 111, 2020. 